\title{
Discourse of Islam on the Online Forum Discourse Analysis of Users' Postings in Subforum News and Politics Kaskus
}

\author{
Yudha Wirawanda \\ Faculty of Communication and Informatics \\ Muhammadiyah University Surakarta \\ Surakarta, Indonesia \\ yw310@ums.ac.id
}

\author{
Rino Andreas \\ Faculty of Communication and Informatics \\ Muhammadiyah University Surakarta \\ Surakarta, Indonesia \\ Khairul Syafuddin \\ Faculty of Communication and Informatics \\ Muhammadiyah University Surakarta \\ Surakarta, Indonesia
}

\begin{abstract}
Kaskus is one of the largest forums in Indonesia. One of the subforums in Kaskus is news and politics. Many ideological discourses are contesting in this subforum. One interesting topic in this subforum is a discourse about Islam. Various users construct Islam differently from one another and construct contestation of Islam. Sometimes this contestations have gone with flame wars. This practice is common in this subforum. Users reproduce such culture to discuss certain topic. This research analyses the discourse of Islam in the context of contemporary Indonesian. Researchers study how users construct the discourse of Islam. This research focus on the how is representation of social actors. This analyze based on the discourse approach by Theo Van Leeuwen. The data of this research is users' posts in the threads and their posts history. This research explains how users excludes and includes various ideas related to Islam. Users are contesting certain idea about Islam in Kaskus. This contestation related with netiquette and history of political discourse in this subforum.
\end{abstract}

Keywords-discourse; van Leeuwen; inclusion; exclusion; islam; kaskus

\section{INTRODUCTION}

Kaskus is one of the largest online forum in Indonesia. It has millions of registered users [1]. These users have done many activities. These activities is managed by moderator. Moderator is certain users that have had been choose by Kaskus administrator to manage the activities. Both users and moderators spent their time in forum to post and make threads. Kaskus itself provides many forums that have specific topic. We can discuss any topic from soccer to superstition in different subforum.

One of the subforum in Kaskus is News and Politics. Users can make threads and postings about political situation. This subforum is divided in two categories: local and international news [2]. In the local news, we can find any recent information of varied topics. Usually users discuss and share information about politics in this subforum.

When make threads, users have to share news from mass media. Kaskus only allowed media that already on its list. They make the list based on the reliability. Moderator in Kaskus decided and considered this reliability. Users cannot share information from the media that is not in the list. Thus they can get sanction from moderator.

Kaskus has their own netiquette. This netiquette is called rules. Each subforum has different rules. Moderator made this rules based on the situation of each rules. For the example, in subforum News and Politics, users cannot do flaming. But users in subforum Soccer can do flaming in specific thread [2]. Kaskus made this rules to minimize the friction between users, e.g. flame wars. Sometimes different idea accolades into the heated discussion.

There are always many ideas floated in online forum. Every users has their own opinions. Sometimes they choose words that can lead emotion from other users. David Bell argues that it might happen because less of social cue between users [3] Users feel safe because they don't have to face the others, hence less direct social sanction. It also happens in Kaskus. Users contested their idea differently.

One interesting topic in subforum News and Politics is the discourse of Islam. Islam has become interesting topic especially when it related with national politics situation. This discursive is not new. Islam has become the interesting topic since the Islamisation in Soeharto era and Post-Islamisation since Reformation [4]. This discursive have constructed the contestation in many field, from national politic to popular culture. Ariel Heryanto [4] showed how the public discuss the interpretation and implementation of Islam in certain popular movie and certain music like dangdut. The Islamism is already 
on the rise in contemporary Indonesia. People show their identity and discipline based on Islam value [5].

Islam is the majority religion in Indonesia. But there are some different interpretation and implementation of Islam. For the example the interpretation of Pancasila as nation ideology. Some Islam group accept this interpretation. They argue that Pancasila don't conflict with Islam practice. But some Islam group argue that they must practice pure Islam law and value. This different interpretation has caused interesting discourse of Islam, including in Kaskus. This research tried to analyze of such discursive.

Discourse is related with text, but not only about it. Van Leeuwen stated that discourses are social cognition [6]. Discourse are specific ways of knowing social practices. We can use discourse as resources for representing social practices in text [6]. In this research, we focused on the texts that represent social actors in the discursive. We analyzed how users using inclusion and exclusion technique to represent social actors. This inclusion and exclusion will be analyze with the context of discourse of Islam in contemporary Indonesia.

\section{METHOD}

We use the discourse analyze approach from Theo Van Leuuwen. We focus on how users did the inclusion and exclusion about Islam in threads. This technique can explain the representation of social actors in text [7], [6]. We made eighteen threads that share news related with Islam. Then we analyze the postings. We reduced in based on the research focus. Then we analyzed the postings with the concept of inclusion and exclusion and the discourse of Islam. We also comprehended the users' and discourse history in this subforum regarding the topic.

\section{RESULT AND DISCUSSION}

\section{A. Discourse of Islam in Subforum}

News and Politics always provides up-to-date information, especially about politics. This subforum started to relate the discourse of Islam with national politics since Jakarta Gubernatorial Election in 2012. This political event got national attention.

One of the candidate was supported by PKS. PKS according to Yunanto one of political party based on the ideology of Islam. PKS is modern party that try to construct modernist Islam [8]. PKS try to implement Sharia Law in national politics. However this party has different approach than HTI [9].

But in Kaskus, some users have found it differently. In the polarization of national politics, users have tended to categorize PKS and such organization that oppose nationalist interpretation of Islam in the same page. They put users that oppose Joko Widodo in one group, called panasbung, abbreviation of pasukan nasi bungkus. Omit, users that have opposed Joko Widodo reject this grouping. They refuse to admit the allegations that they try to change the Pancasila with Sharia Law. They have alleged the opposition as liberal that try to make Indonesian into a secular state. They also use term to call the opposition with panastak, abbreviation of pasukan nasi kotak.

This contestation wasn't ended in 2012. It has continued in Presidential Election in 2014, Jakarta Gubernatorial Election in 2017, until now. Some users using the terms and strategy to delegitimize the oppositional idea of Islam in national politics. The discourse itself of course has not diametric. But some users usually try to take the discourse in the context of panastak vs panasbung. Yunanto argue that the discourse of Islam in Indonesia is varied. There are national point of view that represented in large Islamic Organization such as NU and Muhammadiyah. But also there are various oppositional groups that reject the idea of Pancasila and try to implement Sharia Law. This oppositional groups are various from the moderate to the extreme ones. There are also groups that interpret Islam more liberal and secular [9].

But users usually ignores such varied interpretations. They have tended to stuck in the polarization of panastak vs panasbung, pro or oppose Joko Widodo. This culture is already constructed and stabilized in this subforum. Hence the strategy of inclusion and exclusion always comprehend with this situation.

\section{B. Exclusion and Inclusion of Extreme Ideology}

Users have excluded certain interpretation of Islam based on their own point of view. Users that tend to support Joko Widodo usually exclude the interpretation of panasbung about Islam. They also include some interpretations if Islam in the same group.

One way to do the inclusion is "overdetermination". "Overdetermination" occurs when social actors are represented as participating in more than one social practice [9]. In this subforum, the "overdetermination" of stereotypical. Sometimes they use symbolization, technique to show a "fictional" social actor or group of social actors stands for actors or groups in nonfictional social practices. For the example some users symbolized panasbung as anti-Pancasila, pro-khilafah, and pro terrorism. Alleged users rejected this symbolization and stigmatization. But this has shown in the terms that frequently show in the threads.

TABLE I. MOST FREQUENT TERMS
\begin{tabular}{|c|c|}
\hline Terms & Frequently \\
\hline Khilafah & 26 \\
\hline Teroris & 21 \\
\hline Nasbung & 20 \\
\hline Muslim & 16 \\
\hline FPI & 16 \\
\hline Islam & 15 \\
\hline Pancasila & 15 \\
\hline HTI & 12 \\
\hline ISIS & 11 \\
\hline
\end{tabular}


Some users put khilafah, terrorist, and nasbung in one group. Users used some terms to include the group that in national politics situation opposing current government. This groups include FPI or HTI. The data show that one other technique of inclusion is with association. Association is one technique to associate group in labeled category in the text [9]. Some users associated terrorist with panasbung. They try to correlate the extreme interpretation of Islam with their oppositional group. This association is unfair because the object reject the allegation.

The alleged group, panasbung, eventually, have used exclusion technique to distinguish themselves with extreme ideology. FPI always try to distinguish themselves with radicalism [10]. They refuse to associate themselves with antiPancasila or extreme pro-khilafah. Sometimes these users used suppresion technique. In suppression, there is no reference to the social actors in question anywhere in the text [9]. Users didn't admit or even mentioned the relation between anti-Joko Widodo with pro-terrorism.

Some users also used backgrounding. In backgrounding, some groups are pushed into the background. They excluded terrorist act from Islam value. They even use aggregation to include themselves with majority and automatically exclude from terrorism. Aggregation itself quantifies groups of participants, treating them as statistics [9]. It is important in democratic society to argue with percentage. Users showed the data how extreme groups are minority.

They also used differentiation. Differentiation explicitly differentiates a group or individual of social actors from a similar actor or group [9]. It creates the difference between the "self" and the "other". Some users posted the rationalization that they don't support extreme act. They argued that real Islam won't hurt others, thus terrorism is different with Islam.

In this subforum users that alleged with terrorism usually rejected the allegation. They defend their position also with exclusion and inclusion. This is because the culture already stabilized the diametrical discourse of national politics. Both panasbung and panastak reject radical and extreme interpretation of Islam. But in the discursive situation, some users usually indicted that their opposition is radical with inclusion and exclusion technique. The alleged users eventually also use those techniques to defend their ideology.

\section{Role of Netiquette in Inclucion and Exclusion}

In subforum News and Politics, the inclusion and exclusion has not blatant. One of the factor is because of the netiquette. Each subforum has its own rules. Netiquette is set of rules to organize online interaction [1]. Some online act may lead to heated conversation. That is why Kaskus made several rules to control users' interaction.

One of the rules in this subforum that users cannot share information from media that's not in the list [11]. Moderator arranged the list based on their consideration. We argue that one factor is based on the radical ideology of media and reliability. Other rules that users cannot post that discriminate ethnicity, race, groups, or religion. Moderator would ban users account if they violate the rules.

These rules have affected how users do inclusion and exclusion. They cannot be blatantly mention religion or use harsh word to accuse other users. Based on the observation, most of the users in this subforum are now newbie. They already understand the culture and netiquette in this subforum. Bell argued that we can use cyberspace to destabilize or legitimize culture [1]. In this case, users tended to stabilize the polarization between panastak and panasbung.

That is why users have done inclusion and exclusion technique, like backgrounding and symbolization. These technique is less frontal. The netiquette and stabilized cyberculture conditioned users to practice in certain ways. The condition, legitimized also by users' activities, structured the discourse of Islam. The discourse of Islam in subforum News and Politics eventually stuck in the polarization between us vs them, panastak vs panasbung. This situation is not ideal, but in democracy this is reasonable as long as this is not affecting the heated polarization in real life.

\section{CONCLUSION}

Users in subforum News and Politics use inclusion and exclusion technique to support their idea. The discourse of Islam in this subforum always related with national politics. The condition and culture in this subforum tend to stabilize the polarization of ideology. For the next research, will be interesting to analyse the users' ideology with deepth interview.

\section{ACKNOWLEDGMENT}

We would like to thank to Allah SWT for His blessings. This research was supported by LPPI of Universitas Muhammadiyah Surakarta. We thank to our department and program to realize this paper.

\section{REFERENCES}

[1] Y. Wirawanda, "Prosumption Flaming Fans Sepakbola Virtual [Preseumption Flaming of Sepakbola Virtual Fans]," 2017, in Komunikasi Berkelanjutan dalam dinamika Media dan Budaya [Sustainable Communication in Media and Culture's Dynamics], F. G. Sukmono and Nurudin, Ed., Yogyakarta: Buku Litera Yogyakarta, 2017, pp. 99-120.

[2] “Berita dan Politik - Forum [News and Politics - Forum],” Kaskus.com. [Online]. Available: https://www.kaskus.co.id/forum/10/berita-danpolitik.

[3] D. J. Bell, Cyberculture: The Key Concepts. London: Routledge, 2004.

[4] A. Heryanto, Identitas dan Kenikmatan [Identity and Pleasure], Kepustakaan Populer Gramedia, 2015.

[5] M. Sakai and A. Fauzia, "Islamic orientations in contemporary Indonesia: Islamism on the rise?" Asia. Ethnic., vol. 15, no. 1, pp. 41-61, 2014.

[6] T. van Leeuwen, Discourse and Practice: New Tools for Critical Discourse Analysis, Oxford: Oxford University Press, 2008.

[7] D. Syariati, "Geliat Suara Perempuan Muslim di Facebook [The Commencing Movement of Muslim Women Voice on Facebook]," Surakarta: Komuniti, vol. 9, no. 2, pp. 98-104, 2017. 
[8] K. Hamayotsu, "Beyond faith and identity: mobilizing Islamic youth in a democratic Indonesia." The Pacif. Rev., vol. 24, no. 2, pp. 225-247. 2011.

[9] S. Yunanto, Islam Moderat vs Islam Radikal: Dinamika Politik Islam Kontemporer [Moderate Islam vs Radical Islam: The Dynamics of Contemporary Islamic Politics], Yogyakarta: Medpress, 2018.

[10] M. Woodward, M. Yahya, I. Rohmaniyah, D. M. Coleman, C. Lundry, and A. Amin, "The Islamic Defenders Front: Demonization, Violence and the State in Indonesia," Contemp. Isl., vol. 8, no. 2, pp. 153-171, 2014.

[11] "Undang-undang Baru Forum Berita dan Politik [New Rules of News and Politics Forum]," Kaskus.com. [Online]. Available: https://www.kaskus.co.id/thread/549ef3321cbfaa0e438b456c/wajibbaca-undang-undang-baru-forum-berita-dan-politik. 